\title{
ANALISIS DETERMINAN EFISIENSI BANK UMUM SYARIAH INDONESIA DENGAN VARIABEL MODERATING PROFITABILITAS
}

\author{
Ranaswijaya $^{1}$, Ari Kristin $\mathbf{P}^{\mathbf{2}}$, Muhlis ${ }^{\mathbf{3}}$ \\ UIN Walisongo Semarang \\ $\bowtie$ ari.kristin@gmail.com
}

\begin{abstract}
The purpose of this study is to examine the effect of Non Performing Financing (NPF) and Bank Size on the profitability and efficiency level of Islamic Commercial Banks, as well as the effect of profitability if it moderates the effect of Non Performing Financing (NPF) and Bank Size on the level of efficiency of Islamic Commercial Banks. The level of efficiency is obtained through efficiency analysis with Data Envelopment Analysis (DEA), The variables of input output consist of tabungan $i B$, giro $i B$, and deposito $i B$, while output consist of murabahah financing, mudharabah financing, musyarakah financing,and investment in securities. Data used during the period 2014-2017 which includes 13 Islamic Commercial Banks. The results of the study indicate that Bank Victoria Syariah achieved optimal efficiency values and the lowest efficiency of Bank Syariah Bukopin. The results of the hypothesis indicate that Non Performing Financing (NPF) has a significant negative effect on profitability and the level of efficiency of Islamic commercial banks. Bank size has no significant positive effect on profitability and has no significant negative effect on the efficiency of Islamic commercial banks. Profitability has no significant positive effect on the level of efficiency, and is not able to significantly moderate the influence of NPF and bank size on the level of efficiency of Islamic commercial banks.
\end{abstract}

Keywords $\quad$ : efficiency, islamic commercial bank, Data Envelopment Analysis (DEA).

\section{LATAR BELAKANG}

Bank Umum Syariah mengalami pasang surut dalam perkembangannya. Hal ini dapat dilihat dari tidak sebandingnya perkembangan pendapatan bank terhadap total asset, dana pihak ketiga dan pembiayaan bank. Perkembangan BUS pada tahun 2014 sampai dengan tahun 2017 ditunjukkan pada tabel 1. Berdasarkan tabel tersebut dapat dipahami bahwa dari tahun 2014 sampai dengan tahun 2017, asset, DPK dan pembiayaan mengalami peningkatan, namun pendapatan bersih pada tahun 2015 turun menjadi 635 Milyar dibandingkan tahun 2014 yakni 702 Milyar, dan naik kembali pada tahun 2016 dan 2017.

Sebagai lembaga intermediasi atau penghubung antara pemilik dana dengan pihak pengguna dana, BUS mempunyai posisi strategis dalam perekonomian Indonesia. Semua pihak mulai dari pemilik modal, nasabah, pengguna jasa, Bank 
Indonesia dan Otoritas Jasa Keuangan yang berfungsi sebagai pengawas, maupun pemerintah memiliki kepentingan terhadap kondisi keuangan maupun non keuangan bank syariah. Bank dengan kondisi keuangan yang baik, mampu mempengaruhi banyak pihak untuk memanfaatkannya.

Tabel 1 Perkembangan Total Asset, DPK, Pembiayaan dan Pendapatan Bersih Bank Umum Syariah 2014-2017

Sumber: Laporan SPS dan Bank Aceh Syariah, dikelola

(Dalam Milyar Rupiah)

\begin{tabular}{lllll}
\hline \multirow{2}{*}{ Indikator } & \multicolumn{4}{c}{ Tahun } \\
\cline { 2 - 5 } & \multicolumn{1}{c}{$\mathbf{2 0 1 4}$} & $\mathbf{2 0 1 5}$ & $\mathbf{2 0 1 6}$ & \multicolumn{1}{c}{$\mathbf{2 0 1 7}$} \\
\hline Total Asset & 204,961 & 213,423 & 254,184 & 288,027 \\
Dana Pihak Ketiga & 170,723 & 174,895 & 206,407 & 238,225 \\
Total Pembiayaan & 147,994 & 153,968 & 177,582 & 189,789 \\
Pendapatan Bersih & 702 & 635 & 952 & 987 \\
\hline
\end{tabular}

Menjaga kesehatan keuangan merupakan hal yang penting, karena kondisi tersebut dapat digunakan oleh pihak-pihak terkait untuk mengevaluasi kinerja keseluruhan dari aktivitas bank. Salah satu caranya adalah dengan penerapan efisiensi (Yahya, 2014). Efisiensi sering diartikan bagaimana suatu perusahaan, dalam hal ini bank dapat memperoleh laba dengan pemanfaatan sumber daya bank yang dimiliki, tetapi tidak sekedar itu efisiensi juga menyangkut pengelolaan hubungan input dan output, yaitu bagaimana mengalokasikan sumber daya yang tersedia secara optimal untuk dapat menghasilkan output yang maksimal sehingga menghasilkan kinerja yang baik (Abidin dan Endri, 2009).

Non Performing Financing (NPF) merupakan istilah yang digunakan untuk rasio pembiayaan bermasalah dalam perbankan syariah. NPF lebih dikenal dengan nama Non Performing Loan (NPL) di dalam bank konvensional. Semakin tinggi rasio ini, menunjukkan kualitas pembiayaan bank syariah semakin buruk dan ikut mempengaruhi pencapaian laba bank, sehingga pengelolaan pembiayaan sangat diperlukan oleh bank, mengingat fungsi pembiayaan sebagai penyumbang pendapatan terbesar bagi bank syariah (Suhada, 2009).

Fajria (2016) menyatakan bahwa bank size memiliki pengaruh positif dan signifikan terhadap profitabilitas, hal senada dinyatakan oleh Perwitaningtyas (2014). Permana dan Adityawarman (2015) menyatakan bank size berpengaruh secara positif terhadap profitabilitas dan tidak memiliki pengaruh yang signifikan terhadap tingkat efisiensi bank syariah. Dapat dikatakan tidak selalu perbankan syariah dengan ukuran yang besar yaitu yang memiliki aset yang besar dapat lebih efisien. Nurwulan (2012) menyatakan bank size mempengaruhi efisiensi secara positif signifikan.

Berdasarkan uraian di atas penulis tertarik meneliti lebih lanjut bagaimana efisiensi bank umum syariah dan menguji pengaruh Non Performing Financing (NPF) dan Bank Size terhadap profitabilitas dan tingkat efisiensi bank umum syariah, serta pengaruh profitabilitas jika memoderating pengaruh Non Performing Financing (NPF) dan Bank Size terhadap tingkat efisiensi bank umum syariah. 


\section{TEORI DAN METODE}

\subsection{Konsep Efisiensi Bank Umum Syariah}

Kemampuan menghasilkan output yang maksimal dengan input yang ada merupakan ukuran kinerja yang diharapkan. Pada saat pengukuran efisiensi dilakukan, lembaga keuangan dihadapkan pada kondisi bagaimana mendapatkan tingkat output yang optimal dengan input yang ada atau dengan cara mendapatkan tingkat input yang minimum dengan tingkat output tertentu (Novandra, 2014). Suatu bank, termasuk kategori efisien apabila menggunakan jumlah unit input yang lebih sedikit bila dibandingkan dengan unit input yang digunakan oleh bank lain dalam menghasilkan output yang sama. Atau, dengan menggunakan unit input yang sama dapat menghasilkan jumlah output yang lebih besar dibandingkan bank lain. Bank yang lebih efisien umumnya akan menunjukkan kinerja yang lebih baik jika dibandingkan dengan bank yang kurang efisien (Dewi, 2016).

Menurut Farrel dalam Machmud dan Rukmana (2010), efisiensi perusahaan terdiri dari dua komponen yaitu efisiensi teknis dan efisiensi alokatif. Efisiensi teknis mencerminkan kemampuan perusahaan dalam menghasikan output dengan sejumlah input yang tersedia. Sementara itu, efisiensi alokatif mencerminkan kemampuan perusahaan dalam mengoptimalkan pengunaan inputnya, dengan struktur harga dan teknologi produksinya. Kedua ukuran ini kemudian dikombinasikan menjadi efisiensi ekonomi. Suatu perusahaan dapat dikatakan efisiensi secara ekonomi jika perusahaan tersebut dapat meminimalkan biaya produksi untuk menghasilkan output tertentu dengan suatu tingkat teknologi yang umumnya digunakan suatu harga pasar yang berlaku.

Secara umum, ada dua pendekatan untuk mengukur tingkat efisiensi perbankan, termasuk dalam hal ini bank umum syariah yaitu pendekatan nisbah keuangan dan pendekatan Operating Reseach (OR). Pendekatan Nisbah Keuangan: pendekatan ini merujuk pada kinerja keuangan, diantaranya ROA, ROE, BOPO. Pendekatan Operating Reseach (OR) meliputi parametrik dan non-parametrik. Salah satu teknik non parametrik adalah Data Envelopment Analysis (DEA) (Hidayat, 2014).

Berdasarkan pendekatan nisbah keuangan bank dinilai memiliki efisiensi yang tinggi apabila rasio ROA, ROE dan BOPO tinggi dan sebaliknya serta tidak perlu analysis mendalam karena sudah ditampilkan pada laporan keuangan. Sedangkan dalam pendekatan OR harus melalui analisis dahulu untuk mengetahui tingkat efisiensi bank. Adapun pada penelitian ini, dilakukan dengan pendekatan OR melalui test statistik non parametrik mengunakan Data Envelopment Analysis (DEA).

\subsection{Konsep Efisiensi dalam Islam}

Efisiensi dalam dalam Islam dikaitkan dengan upaya mendapatkan keuntungan optimal yang diiringi dengan usaha yang optimal dengan tetap menjaga keseimbangan dan etika syariah. Keuntungan yang didapat sesuai dengan kerja keras dan beban yang dikeluarkan (Ali dan Ascarya, 2010). Keseimbangan juga berarti bahwa dalam mewujudkan value added, produsen mesti memperhatikan aspek sosial, 
ekonomi, dan lingkungan. Menurut hukum Islam, optimalisasi dan keseimbangan dapat dicapai dengan beberapa pedoman, diantaranya (Ali dan Ascarya, 2010):

\section{a. Spesialisasi kerja}

Prinsip dasar tentang spesialisasi dapat ditelaah dalam hadits Nabi SAW yang menjelaskan tentang konsep Itqan. Mengenai itqan, Rasulullah saw bersabda yang artinya:

"Sesungguhnya Allah mencintai jika seseorang melakukan pekerjaan (berproduksi) dengan cermat dan tekun (itqan) " (HR. Thabrani).

Itqon adalah berusaha untuk memperoleh hasil yang optimal dengan standar ideal secara teknis (Choiriyati, 2011). Konsep Itqan memberikan penilaian lebih terhadap hasil pekerjaan yang sedikit atau terbatas, tetapi berkualitas, dari pada output yang banyak, tetapi kurang bermutu. Efisiensi merupakan upaya mengoptimalkan sumber daya agar mencapai hasil optimal, sehingga bisa dipahami bahwa efesiensi merupakan hal yang seprinsip dengan itqon.

\section{b. Larangan tabdzir dan israf}

Al-Mawardi menjelaskan bahwa israf adalah kesalahan menggunakan takaran yang tepat, sedangkan tabdzir adalah kebodohan dalam menggunakan alokasi yang tepat. Tabdzir tidak banyak disebut dalam al-Qur'an, hanya 3 kali di dalam 2 ayat dan 1 surat. Sedangkan isrof lebih banyak disebut yakni sebanyak 23 kali di dalam 21 ayat dan 17 surat (Alifah, 2016). Ayat al-Qur'an terkait tabdzir dan isrof adalah yang artinya:

"Dan berikanlah kepada keluarga-keluarga yang dekat akan haknya, kepada orang miskin dan orang yang dalam perjalanan dan janganlah kamu menghambur-hamburkan (hartamu) secara boros. Sesungguhnya pemborospemboros itu adalah saudara-saudara syaitan dan syaitan itu adalah sangat ingkar kepada Tuhannya" (QS. Al-Israa': 26-27)"

"Hai anak Adam, pakailah pakaianmu yang indah di setiap (memasuki) masjid, Makan dan minumlah, dan janganlah berlebih-lebihan. Sesungguhnya Allah tidak menyukai orang-orang yang berlebih-lebihan" (QS. Al-A'raaf': 31)"

Ayat diatas menjelaskan larangan boros dan menafkahkan harta secara wajar. Tabdzir (boros) adalah menyia-yiakan harta dan membelanjakan secara tidak wajar (Az-Zuhaili, 2016). Isrof adalah melebihi batas yang dibutuhkan (Az-Zuhaili, 2016). Harta haruslah digunakan untuk hal benar dan tidak berlebh-lebihan. Menurut Nopirin (1997) efisiensi adalah tindakan yang tidak melakukan pemborosan. Berdasarkan uraian tersebut dapat dipahami bahwa efisiensi merupakan tindakan yang tidak boros dan sesuai dengan ajaran Islam.

\subsection{Data Envelopment Analysis (DEA)}

DEA adalah suatu teknik pemrograman matematika untuk mengukur tingkat efisiensi dari Unit Pengambilan Keputusan (UPK) atau Decision Making Unit (DMU) relatif terhadap UPK yang sejenis ketika dalam keadaan tidak optimal (Hidayat, 2014). Abidin dan Endri (2009) menyatakan DEA adalah sebuah metode pengukuran efisiensi dengan mengunakan model program linier untuk menghitung perbandingan rasio output dan input untuk semua unit yang dibandingkan dalam sebuah populasi. Skor efisiensi untuk setiap unit adalah relatif, tergantung pada tingkat efisiensi dari 
unit-unit lainnya di dalam sampel. Setiap unit dalam sampel dianggap memiliki tingkat efisiensi yang tidak negatif, dan nilainya antara 0 dan 1 dengan ketentuan satu menunjukkan efisiensi yang sempurna.Ada dua model yang sering digunakan dalam pendekatan ini, yaitu Constant Return to Scale (CRS) dan Variabel Return to Scale (VRS).

1) Constant Return to Scale (CRS)

Model Constant Return to Scale dikembangkan oleh Charnes, Cooper, dan Rhodes (Model CCR) pada tahun 1978. Asumsi model ini adalah jika ada tambahan input sebesar " $\mathrm{x}$ " kali, maka menyebabkan output meningkat sebesar " $\mathrm{x}$ " kali juga, atau dengan kata lain rasio penambahan input dan output adalah sama.

2) Variabel Return to Scale (VRS)

Model ini dikembangkan oleh Banker, Charnes, dan Cooper (Model BCC) pada tahun 1984 dan merupakan pengembangan dari model CCR. Asumsi model ini adalah bahwa rasio penambahan input dan output tidak sama. Artinya, penambahan input sebesar " $x$ " kali tidak menyebabkan output meningkat sebesar " $x$ " kali, bisa lebih kecil atau lebih besar Machmud dan Rukmana (2010).

Terkait dengan penetuan variabel input dan output, umumnya dilakukan dengan pendekatan aset (the assets approach), pendekatan produksi (the production approach) dan pendekatan intermediasi (the intermediation approach).

1) Pendekatan Aset (The Assets Approach): Pendekatan aset mencerminkan fungsi primer sebuah lembaga keuangan sebagai pencipta kredit pinjaman (loans). Dalam pendekatan ini, ouput benar-benar didefinisikan kedalam bentuk asset (Muharam dan Pusvitasari, 2007).

2) Pendekatan Produksi (The ProductionApproach): Pendekatan ini menganggap bank sebagai produsen dari kegiatan penghimpunan (funding) dan dan penyaluran (lending) dana. Sehingga sisi funding bank maupun sisi financing bank tergolong sebagai input. Sedangkan output pada tingkat return dan pendapatan lain yang diperoleh bank seperti nisbah bagi hasil, margin, fee dan pendapatan administrasi (Yahya, 2014).

3) Pendekatan Intermediasi (The Intermediation Approach): Pendekatan ini memandang sebuah bank sebagai intermediator, yakni menerima dana dari nasabah yang surplus dana kemudian menyalurkannya kepada nasabah yang defisit dana untuk dikelola, input seperti Dana Pihak Ketiga (DPK), modal dan biaya. Sedangkan output seperti pembiayaan dan investasi (Yahya, 2014).

Keunggulan DEA dibandingkan dengan yang lainnya yaitu Analisis DEA didesain khusus untuk menilai efisiensi unit yang memiliki multi input dan multi output, yang biasanya sulit disiasati secara sempurna oleh teknik analisis lainnya seperti analisis rasio dan regresi. Analisis rasio mengukur efisiensi dengan cara membandingkan nilai output dengan nilai input. Pada saat terjadi multi output dan multi input bisa terjadi banyak hasil perhitungan dan pertimbangan. Analisis regresi menyusun suatu model dari tingkat output tertentu sebagai fungsi dari berbagai tingkat input tertentu, 
untuk membandingkan kemampuan unit lain dalam menghasilkan output. Unit yang efisien jika menghasilkan output yang lebih besar daripada nilai estimasi. Tetapi jika outputnya banyak maka analisis regresi juga tidak menghasilkan nilai yang memuaskan, karena satu persamaan regresi hanya menampung satu input, jika dilakukan penggabungan banyak input maka informasinya menjadi tidak rinci (Mulyadi, 2015). Manfaat analisis dengan DEA meliputi scoring and ranking, performance improvement, benchmarking, resources allocation, optimum operational scale, dan cross efficiency analysis (Mulyadi, 2015)

\subsection{Non Performing Financing (NPF)}

Non Performing Financing (NPF) merupakan istilah yang digunakan untuk rasio pembiayaan bermasalah dalam perbankan syariah. NPF lebih dikenal dengan nama Non Performing Loan (NPL) di dalam bank konvensional. Menurut Siamat (2005) menyatakan pembiayaan bermasalah adalah pinjaman yang mengalami kesulitan pelunasan akibat adanya faktor kesengajaan dan atau karena faktor eksternal diluar kemampuan kendali nasabah peminjam, Fidyaningrum dan Jannah (2016) menyatakan pembiayaan bermasalah adalah suatu keadaan dimana nasabah sudah tidak sanggup membayar sebagaian atau seluruh kewajibannya kepada bank seperti yang telah diperjanjikan.

Teguh Pudjo Mulyono (1995) dalam Rahman dan Rochmanika (2012) menyatakan NPF adalah rasio yang digunakan untuk mengukur kemampuan manajemen bank dalam mengelola pembiayaan bermasalah yang ada dapat dipenuhi dengan aktiva produktif yang dimiliki oleh suatu bank, Stiawan (2009) menyatakan NPF adalah jumlah pembiayaan yang bermasalah dan kemungkinan tidak dapat ditagih, semakin besar nilai NPF maka semakin buruk kinerja bank tersebut. Pembiayaan bermasalah atau NPF berarti pembiayaan yang pelaksanaannya belum mencapai atau memenuhi target yang diinginkan pihak bank. Windriya (2017) menyatakan perhitungan NPF mengunakan rumus berikut:

$$
N P F=\frac{\text { Jumlah Pembiayaan Bermasalah }}{\text { Total Pembiayaan }} \times 100 \%
$$

NPF tetap menjadi momok yang menakutkan bagi perbankan. Apalagi, pengalaman membuktikan bahwa salah satu penyebab krisis ekonomi adalah kinerja perbankan yang buruk. Tingginya NPF, khususnya kredit macet, memberikan kontribusi besar pada buruknya kinerja perbankan pada saat itu. NPF menjadi salah satu indikator sehat tidaknya sebuah bank (Maidalena, 2014). Penilaian kualitas pembiayaan dapat digolongkan menjadi lancar (tepat waktu), dalam perhatian khusus (sampai 90 hari), kurang lancar ( 90-180 hari), diragukan (180-270 hari) dan macek (melewati 270 hari) (Trisadini, 2013).

\subsection{Bank Size}

Karakteristik bank yang tidak kalah penting adalah ukuran bank (Bank Size). Semakin besar suatu bank maka kecenderungan penggunaan dana juga semakin besar. Bank yang memiliki banyak asset akan dapat meningkatkan kinerjanya yang berpotensi untuk menghasilkan laba lebih baik. Meningkatnya asset akan mendororng tingkat 
likuiditas bank sehingga dapat meningkatkan modal bank. Bank berukuran besar relatif memiliki keunggulan dari pada bank berukuran yang lebih kecil (Permana dan Adityawarman, 2015).

Mawardi (2014) menyatakan bahwa asset bank didominasi oleh asset keuangan, berupa kredit yang diberikan, surat berharga yang dimiliki, simpanan pada bank Indonesia maupun simpanan pada bank lain. Sehingga total asset bank syariah didominasi oleh pembiayaan yang disalurkan, surat berharga yang dimiliki, penempatan pada Bank Indonesia, dan penempatan pada bank lain. Adapun pada penelitian ini ukuran tersebut diproksikan kedalam bentuk logaritma natural agar memberikan besaran angka yang lebih sesuai dengan variabel lain. Sehingga ukuran bank size pada penelitian ini dirumuskan sebagai berikut:

Bank Size = Ln (PD + SB + PBI + PBL)

Keterangan :

Ln : Logaritma Natural

PD : Pembiayaan yang Disalurkan

SB : Surat berharga yang dimiliki

PBI : Penempatan pada Bank Indonesia

PBL: Penempatan pada Bank Lain

\subsection{Profitabilitas Bank Umum Syariah}

Kinerja keuangan bank adalah suatu ukuran yang menggambarkan kondisi keuangan suatu bank. Bagi nasabah, sebelum memutuskan menjadi nasabah di suatu bank mereka akan melihat lebih dahulu kinerja keuangan bank tersebut melalui laporan keuangan berupa neraca dan laba rugi. Salah satu indikator untuk menilai kinerja keuangan suatu bank adalah melihat tingkat profitabilitasnya.Hal ini terkait sejauh mana bank menjalankan usahanya.Semakin tinggi profitabilitas suatu bank, maka semakin baik pula kinerja bank tersebut (Stiawan, 2009). Ukuran profitabilitas yang digunakan adalah Return on Asset (ROA) dan Return on Equity (ROE).

Indikator yang digunakan untuk mengukur tingkat profitabilitas bank dalam penelitian ini adalah Return On Asset (ROA). Alasan penggunaan ROA karena mampu mengakomodasi berbagai pihak yang berkepentingan dengan bank, antara lain investor, nasabah, internal bank dan pemerintah (Wicaksari, 2015). ROA menunjukkan kemampuan manajemen mendayagunakan asset untuk meraih keuntungan sehingga dengan ROA dapat diketahui kemampuan setiap unit asset dalam menghasilkan keuntungan sebagai cerminan kemampuan manajemen dalam mengelolanya (Mawardi, 2014).

Haq (2015) menyatakan ROA merupakan rasio yang digunakan untuk mengetahui kemampuan bank dalam menghasilkan keuntungan dari pengelolaan asset yang dimiliki oleh bank. Restuningdiah (2010) menyatakan ROA adalah rasio yang digunakan untuk mengukur keuntungan bersih yang diperoleh dari pengunaan asset atau aktiva. Hardiyanti (2015) ROA merupakan rasio antara laba setelah pajak (earning after tax) terhadap total asset yang dimiliki bank, apabila bank memiliki ROA yang tinggi menunjukkan bahwa bank tersebut memiliki kemampuan yang besar dalam meningkatkan laba. Berdasarkan ketentuan Surat Edaran Bank Indonesia 
nomor 3/30/DPNP tahun 2011 menyatakan perhitungan ROA mengunakan rumus berikut:

$$
R O A=\frac{\text { Laba Sebelum Pajak }}{\text { Total Aset }} \times 100 \%
$$

\subsection{Perumusan Hipotesis}

a. Pengaruh NPF terhadap Profitabilitas

Stiawan (2009) menyatakan bahwa NPF berpengaruh negatif signifikan terhadap profitabilitas, dimana hasil serupa juga dinyatakan Dewi (2010). Rahmi dan Anggraini (2013) menyatakan bahwa NPF memiliki pengaruh positif terhadap profitabilitas. Lemiyana dan Litriani (2016) menyatakan bahwa NPF tidak ada pengaruh terhadap ROA. NPF yang tinggi akan berdampak pada turunnya pendapatan bank yang pada akhirnya menurunkan nilai ROA. Berdasarkan uraian tersebut maka diajukan hipotesis sebagai berikut:
$H 1$ : Non Performing Finance (NPF) berpengaruh negatif terhadap Profitabilitas Bank Umum Syariah

b. Pengaruh NPF terhadap Tingkat Efisiensi

Wahab (2015) menyatakan Non Performing Finance (NPF) berpengaruh negatif terhadap tingkat efisiensi Bank Umum Syariah, hal yang sama juga dinyataka oleh Irawanti (2008). Farandy et al. (2017) menyatakan NPF tidak berpengaruh terhadap efisiensi Bank Umum Syariah namun tanda negatif pada nilai koefisiennya, hal yang sama juga dinyataka oleh Perwitaningtyas (2014). Pambuko (2016) menyatakan bahwa NPF berpengaruh positif dan signifikan terhadap tingkat efisiensi bank umum syariah, hal yang sama juga dinyatakan oleh Nurwulan (2012). NPF yang tinggi akan berdampak pada turunnya pendapatan bank karena tidak optimal dalam mengelolah sumber daya bank yang pada akhirnya bank tidak efisien (inefisien). Berdasarkan uraian tersebut maka diajukan hipotesis sebagai berikut:

H2 : Non Performing Finance (NPF) berpengaruh negatif terhadap tingkat efisiensi Bank Umum Syariah

c. Pengaruh Bank Size terhadap Profitabilitas

Fajria (2016) menyatakan bahwa bank size memiliki pengaruh positif dan signifikan terhadap profitabilitas. Permana dan Adityawarman (2015) menyatakan bank size berpengaruh secara positif terhadap profitabilitas bank syariah. Bank Size yang besar mampu menarik banyak nasabah sehingga pendapatan bank meningkat yang pada akhirnya menaikkan nilai ROA. Berdasarkan uraian tersebut maka diajukan hipotesis sebagai berikut:

H3 : Bank Size berpengaruh positif terhadap Profitabilitas Bank Umum Syariah

d. Pengaruh Bank Size terhadap Tingkat Efisiensi

Permana dan Adityawarman (2015) menyatakan bahwa bank size tidak memiliki pengaruh yang signifikan terhadap tingkat efisiensi bank syariah. Nurwulan (2012) menyatakan bank size memliki pengaruh positif terhadap 
tingkat efisiensi bank syariah, hal yang sama juga dinyatakan oleh Perwitaningtyas (2014). Bank Size yang besar mampu menarik banyak nasabah sehingga bank mampu menghimpun dana dari masyarakat lebih besar dan bisa optimal dalam pemilihan dan penyaluran pembiayaan yang pada akhirnya bank akan efisien. Berdasarkan uraian tersebut maka diajukan hipotesis sebagai berikut:

H4 : Bank Size berpengaruh Positif terhadap Tingkat Efisiensi Bank Umum Syariah

e. Pengaruh Profitabilitas terhadap Tingkat Efisiensi

Wahab (2015) menyatakan bahwa ROA berpengaruh positif tidak signifikan. Permana dan Adityawarman (2015) menyatakan bahwa ROA memiliki pengaruh positif yang signifikan terhadap tingkat efisiensi bank syariah. Pambuko (2016) menyatakan bahwa ROA berpengaruh positif dan signifikan terhadap efisiensi bank. Hal yg sama juga dinyatakan oleh Firdaus dan Hosen (2013). Bank yang mampu menjalankan usahanya dengan baik akan tergambar dari nilai ROA bank yang tinggi, ROA merupakan gambaran pedapatan bank terhadap pengelolaan asset yang dimiliki. Bank dengan ROA tinggi mencerminkan bank tersebut telah optimal dalam memperoleh pendapatan dari pengelolaan assetnya sehingga semakin tinggi ROA semakin efisien bank tersebut. Berdasarkan uraian tersebut maka diajukan hipotesis sebagai berikut:

H5 : Profitabilitas berpengaruh positif terhadap Tingkat Efisiensi Bank Umum Syariah

f. Profitabilitas Memoderasi Pengaruh NPF terhadap Tingkat Efisiensi

Bank menyalurkan pembiayaan dengan harapan untuk dapat memperoleh kembali dana yang diinvestasikan sebagai pendapatan bank. Untuk pembiayaan bermasalah yakni dalam kategori kurang lancar, diragukan dan macet bank mengukurnya dengan besar kecilnya NPF. Semakin besar rasio NPF maka bank dalam kondisi semakin besar resiki pembiayaan yang dihadapi, tingginya resiko pembiayaan memberi peluang terjadinya penurunan pendapatan dari pembiayaan yang telah disalurkan bank (Windriya, 2017). Hal tersebut mengambarkan hubungan negatif antara NPF terhadap probitabilitas bank sepertinya dinyatakan oleh Stiawan (2009) dan Erdah Litriani (2016). Sementara tekait dengan pengaruh profitabilitas para peneliti seperti Permana dan Adityawarman (2015) dan Pambuko (2016) menyatakan adanya hubungan positif antara profitabilitas dengan tingkat efisiensi. Sedangkan pengaruh langsung antara NPF dengan tingkat efisiensi menurut Wahab (2015), Irawanti (2008) dan Farandy et al. (2017) adalah negatif. Penulis membangun asumsi bahwa melalui profitabilitas maka pengaruh negatif antara NPF dengan tingkat efisiensi akan semakin kuat diakibatnya pengaruh negatif antara NPF dengan profitabilitas. Berdasarkan uraian tersebut maka diajukan hipotesis sebagai berikut: 
H6 : Profitabilitas memperkuat pengaruh negatif NPF terhadap Tingkat Efisiensi Bank Umum Syariah

g. Profitabilitas Memoderasi Pengaruh Bank Size terhadap Tingkat Efisiensi

Bank Size memberikan pengaruh yang berbeda terhadap kinerja perusahaan.

Pertama bahwa semakin besar ukuran perusahaan akan menimbulkan biaya yang lebih besar sehingga akan berpengaruh negatif terhadap kinerja perusahaan. Di sisi lain, perusahaan besar memiliki skala dan keleluasaan ekonomis yang menyebabkan hubungan positif antara ukuran perusahaan dengan profitabilitas. semakin besar ukuran bank maka bank tersebut memiliki lebih banyak modal yang dapat digunakan untuk mengadopsi teknologi baru yang dapat meningkatkan laba dan meminimalkan biaya. Sehingga profitabilitas bank akan baik dan bank semakin efisien seperti halnya yang nyatakan oleh Damayanti (2012). Berdasarkan uraian tersebut maka diajukan hipotesis sebagai berikut:

$H 7$ : Profitabilitas memperkuat pengaruh positif Bank Size terhadap Tingkat Efisiensi Bank Umum Syariah

\subsection{Kerangka Berpikir}

Grafik 1. Kerangka Kerja Uji Efisiensi

\begin{tabular}{l} 
Variabel Input \\
1. Tabungan iB \\
2. Giro iB \\
3. Deposito iB \\
\hline
\end{tabular}

\section{Variabel Output}

1. PembiayaanMurabahah

2. Pembiyaan Mudharabah

3. Pembiayaan Musyarakah

4. Investasi pada Surat Berharga
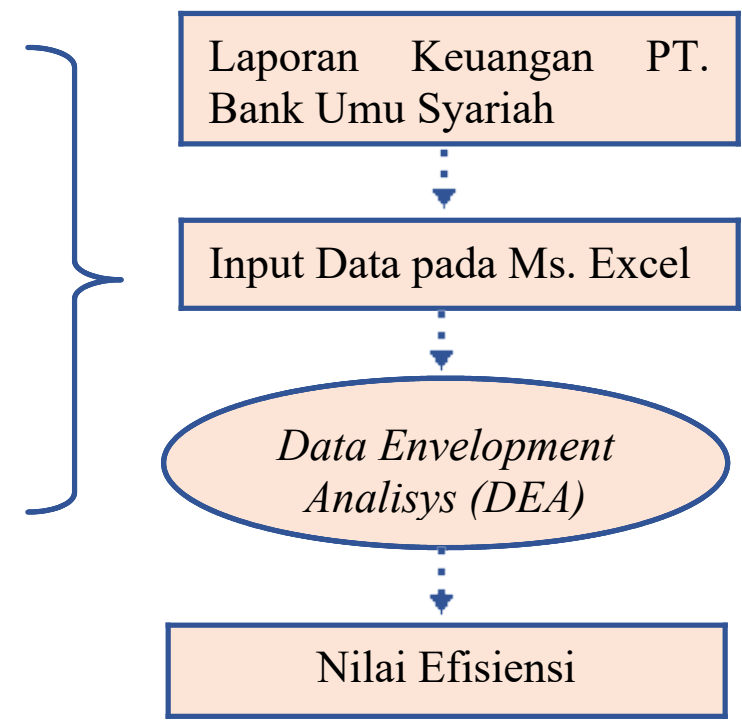
Grafik 1. Kerangka Kerja Uji Hipotesis

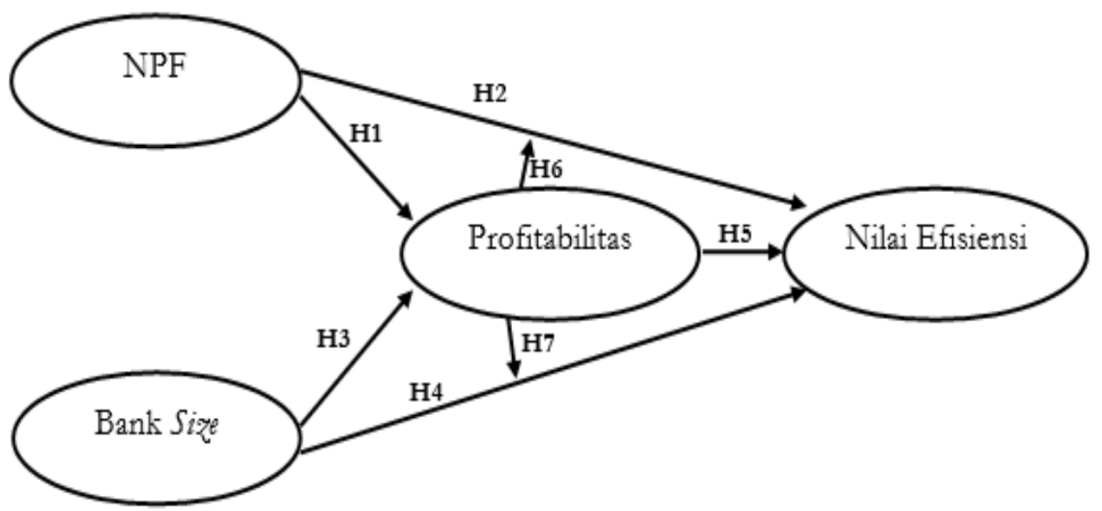

\subsection{Metode Penelitian}

Data yang digunakan dalam penelitian ini adalah data sekunder yang diperoleh dari laporan keuangan tahunan BUS yang dipublikasikan tahun 2014-2017. Bank Umum Syariah yang dijadikan sebagai objek penelitian yakni Bank Muamalat Indonesia, Bank BRI Syariah, Bank BNI Syariah, Bank Syariah Mandiri, Bank Mega Syariah, BCA Syariah, Bank Syariah Bukopin, Bank Jabar Banten Syariah, Bank Victoria Syariah, Maybank Syariah Indonesia, Bank Panin Syariah, BTPN Syariah dan Bank Aceh Syariah.

Variabel independen adalah variabel yang mempengaruhi variabel dependen. Variabel independen memberikan pengaruh baik positif atau negatif. Variabel independen yang digunakan dalam penelitian ini adalah Non Performing Financing (NPF), dan ukuran bank (Bank Size). NPF berdasarkan nilai yang tertera pada laporan keuangan sedangkan bank size dari hasil logaritma natural dari penjumlahan pembiayaan yang disalurkan, surat berharga yang dimiliki, penempatan pada Bank Indonesia, dan penempatan pada bank lain. Variabel dependen adalah variabel yang menjadi inti dari penelitian. Variabel dependen dipengaruhi oleh variabel independen. Selain itu masalah yang ada dalam penelitian tercermin dalam variabel dependen. Penelitian ini menggunakan variabel dependen efisiensi Bank Umum Syariah, yang dihasilkan dari uji efisiensi dengan metode Data Envelopment Analysis (DEA). Nilai efisiensi yang digunakan antara 0-1 yang merupakan hasil dari analisis DEA pada uji efisiensi. Nilai efsiensi didapat dari hasil uji efisiensi dengan variabel input meliputi Tabungan iB, Giro iB, dan Deposito iB serta variable output meliputi pembiayaan murabahah, pembiyaan mudharabah, pembiayaan musyarakah, dan investasi pada surat berharga. Variabel moderating adalah variabel yang dapat memperkuat atau memperlemah hubungan langsung antara variabel independen dengan variabel dependen (Liana, 2009). Variabel moderating pada penelitian ini adalah profitabilitas dengan indikatornya Return On Asset (ROA).

Teknik analisis yang digunakan dalam penelitian ini terdiri dari uji efisiensi dan uji hipotesis. Uji efisiensi dilakukan untuk memperoleh nilai efisiensi. Data yang terkumpul selanjutkan dilakukan validitas data dengan penginputan data dalam Microsoft Excel. Software yang digunakan dalam pengujian efisiensi adalah DEAP Versi 2.1. Dalam pengukuran DEA didahului dengan menentukan bobot (weighted) 
untuk masing-masing input dan output perbankan. Masing-masing perbankan diasumsikan bebas menentukan pembobotan untuk masing-masing variabel, namun harus tetap memenuhi persyaratan yang telah ditentukan. Syarat tersebut meliputi bobot memiliki nilai positif, bobot harus bersifat universal atau tidak menghasilkan indikator efisiensi yang diatas normal atau lebih besar dari 1 bilamana dipakai unit yang lainnya, dan bank dinilai efisien jika memiliki nilai rasio 1 atau 100\%, dan tidak efisien apabila kurang dari 1 atau kurang dari 100\% (Mulyadi, 2015).

Pengujian hipotesis digunakan untuk menjelaskan arah hubungan antara variabel independen dan variabel dependennya. analisis data menggunakan pendekatan Partial LeastSquare (PLS) dengan menggunakan software warpPLS. Hasil korelasi antar konstruk diukur dengan melihat path coefficients dan tingkat signifikansinya yang kemudian dibandingkan dengan penelitian. Suatu hipotesis dapat diterima atau harus ditolak secara statistik dapat dihitung melalui tingkat signifikansinya. Biasanya tingkat signifikansi ditentukan sebanyak 10\%, 5\%, dan 1\% Tingkat signifikansi yang dipakai dalam penelitian ini adalah sebesar 5\%. Apabila tingkat signifikansi yang dipilih sebesar 5\% maka tingkat signifikansi atau tingkat kepercayaan 0,05. Untuk menolak hipotesis. Dalam penelitian ini ada kemungkinan mengambil keputusan yang salah sebesar 5\%. Berikut ini yang digunakan sebagai dasar pengambilan keputusan adalah jika P-value $\geq 0,05$, maka Ho diterima, dan jika P-value $\leq 0,05$, maka Ho ditolak dan Ha diterima.

\section{HASIL DAN PEMBAHASAN}

\subsection{Statistik Deskriptif}

Uji efisiensi Bank Umum Syariah (BUS) mengunakan variabel input Tabungan iB, Giro iB, dan Deposito iB, sedangkan variabel ouput pembiayaan murabahah, pembiayaan mudharabah, pembiayaan musyarakah, dan investasi pada surat berharga. Data diperoleh dari laporan keuangan dan dianalisis dengan softwere DEAP versi 2.1. Hasil pengelolaan data penelitian disajikan pada tabel berikut:

Tabel 2 Kondisi BUS Sudah Efisen, Tidak Efisien, dan Rerata Efisien Bank Umum Syariah 2014-2017

\begin{tabular}{|c|c|c|c|c|c|}
\hline \multirow{2}{*}{ Nama Bank } & \multicolumn{4}{|c|}{ Nilai Efisiensi } & \multirow{2}{*}{$\begin{array}{l}\text { Rata } \\
\text { Rata }\end{array}$} \\
\hline & 2014 & 2015 & 2016 & 2017 & \\
\hline Bank Muamalat & 0,864 & 0,962 & 1,000 & 0,850 & 0.919 \\
\hline Bank BRI Syariah & 0,839 & 0,858 & 1,000 & 1,000 & 0.924 \\
\hline Bank BNI Syariah & 0,975 & 1,000 & 1,000 & 1,000 & 0.994 \\
\hline Bank Syariah Mandiri & 0,803 & 0,925 & 0,845 & 0,985 & 0.890 \\
\hline Bank Mega Syariah & 1,000 & 0,990 & 0,942 & 1,000 & 0.983 \\
\hline BCA Syariah & 0,845 & 0,896 & 0,992 & 0,809 & 0.886 \\
\hline Bank Syariah Bukopin & 0,835 & 0,820 & 0,785 & 0,778 & 0.805 \\
\hline BJB Syariah & 0,962 & 0,879 & 0,872 & 0,927 & 0.910 \\
\hline Bank Victoria Syariah & 1,000 & 1,000 & 1,000 & 1,000 & 1.000 \\
\hline Maybank Syariah & 1,000 & 1,000 & 1,000 & 0,888 & 0.972 \\
\hline Bank Panin Syariah & 1,000 & 1,000 & 1,000 & 0,939 & 0.985 \\
\hline BTPN Syariah & 0,979 & 1,000 & 1,000 & 0,940 & 0.980 \\
\hline Bank Aceh Syariah & - & - & 0,922 & 1,000 & 0.961 \\
\hline
\end{tabular}


Tabel di atas menunjukkan kondisi efisiensi BUS tahun 2014-2017, BUS efisien dengan skor efisiensi 1 atau 100\%, dan tidak efisien dengan skor kurang dari 1 atau 100\%, serta rerata tahunan. Dari 13 BUS ternyata Bank Victoria Syariah mencapai nilai efsiensi optimal yakni 1 atau 100\%, sedangkan yang lainnya tidak mencapai nilai efisiensi optimal yakni kurang dari 1 atau 100\%, BUS dengan nilai efisiensi terendah adalah Bank Syariah Bukopin dengan nilai 0.805 atau 80,5\%. Ketika bank sudah mencapai tingkat efisiensi 1 atau 100\% artinya bank telah mampu mencapai target sedangkan ketika tingkat efisiensi kuang dari 1 atau 100\% artinya bank tidak mampu mencapai target. Nilai yang diperoleh dari output DEAP 2.1. selanjutnya digunakan sebagai nilai efisiensi untuk uji hipotesis.

\subsection{Evaluasi Model Struktural (Inner ModeI)}

Evaluasi model struktural (Inner Model) meliputi Average path coefficient (APC), Average R-squared (ARS), Average Adjusted R-squared (AARS), Average block VIF (AVIF), Average Full Collinearity VIF (AFVIF), Tenenhaus GoF (GoF), Sympson's Paradox Ratio (SPR), R-Squared Contribution Ratio (RSCR), dan Statistical Suppression Ratio (SSR). Data-data disajikan pada tabel berikut:

Tabel 3 Tabel General SEM Analysis Result

\begin{tabular}{lll}
\hline APC, ARS, dan & APC: $0.216, \mathrm{P}=0.026$ & $\begin{array}{l}\text { Diterima: } \\
\text { AARS }\end{array}$ \\
& ARS : $0.263, \mathrm{P}=0.011$ & \\
& AARS: $0.202, \mathrm{P}=0.032$ & \\
\hline R Square & ROA: 0.373 & \\
& EFI: 0.154 & Dapat diterima \\
& AVI: 1.734 & $(\leq 3.3)$ \\
\hline AVIF dan & AFVI: 2.669 & Lemah $\geq 0.1$, \\
AFVIF & GoF: 0.513 & Medium $\geq 0.25$, \\
Tenenhaus & & besar $\geq 0.36$ \\
GoF & & Dapat diterima \\
& SPR: 1.000 & $0.7)$ \\
\hline SPR dan SSR & SSR: 1.000 & Dapat diterima \\
& RSCR: 1.000 & $(\geq 0.9)$ \\
\hline (RSCR) & & \\
\hline
\end{tabular}

Berdasarkan tabel diatas menunjukkan bahwa nilai P-value untuk Average path coefficient (APC), Average R-squared (ARS), dan Average Adjusted R-squared (AARS) sebesar $0.026,0,011$, dan 0,032, nilai ini $<0.05$ sehingga disimpulkan model fit atau layak. Nilai R-Square Coefficientnya yakni sebesar 0.373 dan 0.154 yang berarti $37,3 \%$ kombinasi variabel penelitian dapat mempengaruhi ROA sedangkan $62,7 \%$ dipengaruhi variabel lain diluar faktor penelitian, dan sebesar 15,4\% tingkat efisiensi dipengaruhi oleh kombinasi variabel yang dipilih sedangkan 84.6\% dipengaruhi faktor lain diluar variabel penelitian. Nilai AVIF dan AFVIF sebesar 1.734 dan 2.669, nilai ini < 3,3 yang berarti bahwa model tidak terkena masalah collinearity. Nilai Goodness Tenenhaus (GoF) sebesar 0.513 yang berarti Goodness Of Fit model besar atau sangat baik karena $>0.36$. Nilai Sympson's Paradox Ratio (SPR) dan Statistical Suppression Ratio (SSR) sebesar 1,000. Nilai tersebut $\geq 0.7$, yang berarti tidak ada problem kausalitas di dalam model. Dan nilai R-Squared Contribution Ratio (RSCR) 
sebesar 1.000. Nilai tersebut $\geq 0.9$, yang berarti tidak ada problem kausalitas di dalam model.

\subsection{Pembahasan}

a. Pengaruh Non Performing Financing (NPF) terhadap Profitabilitas

Non Performing Financing (NPF) yang tinggi mengambarkan buruknya kinerja bank (Trisadini, 2013). Pengelolaan pembiayaan sangat diperlukan oleh bank, mengingat fungsi pembiayaan sebagai penyumbang pendapatan terbesar bagi bank syariah. NPF mempengaruhi pencapaian pendapatan bank. Tingginya NPF akan mengakibatkan turunnya pendapatan bank yang pada akhirnya akan menurunkan nilai ROA (Wibowo dan Syaichu, 2013). Berdasarkan uraian tersebut dapat dipahami bahwa secara teoritik NPF berpengaruh negatif terhadap ROA, yakni ketika NPF naik akan menyebabkan turunnya ROA dan sebaliknya.

Hasil penelitian menunjukkan bahwa NPF mempunyai pengaruh negatif dan signifikan terhadap ROA, hal ini dapat dilihat pada hasil perolehan nilai NPF sebesar -0.569 dengan nilai $p$-value sebesar $<0.001$ yang berarti $p$-value $<0.05$. Berdasarkan hasil tersebut maka hipotesis pertama (H1) diterima. Hasil sesuai dengan dugaan awal penelitian yakni NPF berpengaruh negatif terhadap profitabilitas. NPF yang tinggi akan berdampak pada turunnya pendapatan bank yang pada akhirnya menurunkan nilai ROA.

Hasil temuan ini konsisten dengan penelitian yang dilakukan oleh Stiawan (2009) yang menyatakan NPF berpengaruh negatif signifikan terhadap ROA, dimana hasil serupa juga dinyatakan oleh Dewi (2010). NPF mempunyai peranan yang sangat penting, dimana jika rasio tersebut tidak dijaga maka akan menyebabkan kinerja keuangan menurun. Oleh sebab itu, Bank Indonesia melakukan peraturan tentang batas maksimum rasio yang harus dijaga agar tidak melebihi dari batas yang ditentukan. Di sisi lain adanya NPF yang tinggi akan dapat mengganngu perputaran modal kerja dari bank. Maka manakala bank memiliki jumlah pembiayaan macet yang tinggi, bank akan berusaha terlebih dahulu mengevaluasi kinerja mereka dengan sementara menghentikan penyaluran pembiayaannya hingga NPF berkurang.

b. Pengaruh Non Performing Financing (NPF) terhadap Tingkat Efisiensi

Non Performing Financing (NPF) dipakai sebagai proksi dari kualitas pengelolaan pembiayaan, tingkat NPF yang tinggi merupakan refleksi dari kualitas pengelolaan yang rendah dan sebaliknya, tingkat NPF yang rendah menggambarkan kualitas pengelolaan pembiayaan yang baik. Bank dapat menjalankan operasinya dengan baik jika mempunyai NPF di bawah 5\% Perwitaningtyas (2014). Kenaikan NPF yang semakin tinggi menyebabkan cadangan Penyisihan Penghapusan Aktiva Produktif (PPAP) yang ada tidak mencukupi, sehingga pembiayaan bermasalah tersebut harus diperhitungkan sebagai beban yang langsung berpengaruh terhadap pendapatan bank dan berkurangnya modal. Dengan demikian, kenaikan NPF dapat mengakibatkan pendapatan yang dihasilkan oleh bank menurun, sehingga akan membuat bank tersebut menjadi tidak efisien. Berdasarkan uraian tersebut dapat 
dipahami bahwa secara teoritik NPF berpengaruh negatif terhadap tingkat efisiensi, yakni ketika NPF naik akan menyebabkan turunnya tingkat efisiensi dan sebaliknya.

Hasil penelitian menunjukkan bahwa NPF mempunyai pengaruh negatif dan signifikan terhadap tingkat efisiensi, hal ini dapat dilihat pada hasil perolehan nilai NPF sebesar -0.222 dengan nilai p-value sebesar 0.046 yang berarti p-value $<0.05$. Berdasarkan hasil tersebut maka hipotesis kedua (H2) diterima. Hasil sesuai dengan dugaan awal penelitian yakni NPF berpengaruh negatif terhadap tingkat efisiensi. NPF yang tinggi akan berdampak pada turunnya pendapatan bank karena tidak optimal dalam mengelolah sumber daya bank yang pada akhirnya bank tidak efisien (inefisien).

Hasil temuan ini konsisten dengan penelitian yang dilakukan oleh Wahab (2015), Irawanti (2008), Farandy et al. (2017) dan Perwitaningtyas (2014) yang menyatakan Non Performing Finance (NPF) berpengaruh negatif terhadap tingkat efisiensi Bank Umum Syariah.

c. Pengaruh Bank Size terhadap Profitabilitas

Bank size yang besar menyebabkan semakin besar pula profitabilitasnya. Hal ini karena bank memiliki skala dan keleluasaan ekonomis yang menyebabkan hubungan positif antara bank size dengan profitabilitas (Damayanti, 2012). Bank Size yang besar mampu menarik banyak nasabah sehingga pendapatan bank meningkat yang pada akhirnya menaikkan nilai ROA. Berdasarkan uraian tersebut dapat dipahami bahwa secara teoritik Bank Size berpengaruh positif terhadap ROA, yakni ketika bank size naik akan menyebabkan ROA juga naik.

Hasil penelitian menunjukkan bahwa Bank Size tidak pengaruh terhadap ROA karena p-value $>0.05$. Berdasarkan hasil tersebut maka hipotesis ketiga (H3) ditolak. Hasil tidak sesuai dengan dugaan awal penelitian yakni bank size berpengaruh positif terhadap profitabilitas karena secara statistik tidak terbukti signifikan. Semakin besarnya bank size juga memiliki peluang yang lebih besar dalam meningkatkan risiko yang harus ditanggung oleh pihak bank. Hal itu terjadi apabila aset yang dimiliki bank tersebut tidak dikelola dan digunakan secara maksimal untuk kegiatan operasional bank, sehingga bank akan berpotensi mengeluarkan biaya pengelolaan aset yang lebih besar (Pramudita, 2013). Bank size tidak terlalu berkontribusi terhadap profitabilitas bank karena orientasi nasabah pada kemudahan transaksi, sehingga meskipun bank dengan asset kecil jika mampu memberikan layanan yang memudahkan nasabah dalam transaksi, maka bank tetap akan dipilih.

d. Pengaruh Bank Size terhadap Tingkat Efisiensi

Bank size mengambarkan besarnya asset yang dimiliki, sangat penting dalam dunia perbankan karena bank-bank harus memenuhi kebutuhan finansial mereka untuk pembiayaan, investasi, serta layanan keuangan lainnya bagi nasabah dan investor yang semakin mengglobal perilaku operasinya. Menciptakan bank yang efisien, maka bank tersebut haruslah memiliki skala usaha (assets) dan permodalan yang cukup besar (Sugiarto, 2004). Bank size yang besar mampu menarik banyak nasabah sehingga bank mampu menghimpun dana dari masyarakat lebih besar dan bisa 
optimal dalam pemilihan dan penyaluran pembiayaan yang pada akhirnya bank akan efisien. Berdasarkan uraian tersebut dapat dipahami bahwa secara teoritik Bank size berpengaruh positif terhadap tingkat efisiensi, yakni ketika bank size naik akan menyebabkan naiknya tingkat efisiensi.

Hasil penelitian menunjukkan bahwa Bank Size tidak pengaruh terhadap tingkat efisiensi karena p-value $>0.05$. Berdasarkan hasil tersebut maka hipotesis keempat (H4) ditolak. Hasil tidak sesuai dengan dugaan awal penelitian yakni bank size berpengaruh positif terhadap tingkat efisiensi karena secara statistik tidak terbukti signifikan. Hasil temuan ini konsisten dengan penelitian yang dilakukan oleh Permana dan Adityawarman (2015) menyatakan bahwa bank size tidak berpengaruh terhadap tingkat efisiensi bank syariah, bank dengan ukuran yang besar belum lebih efisien dibandingan dengan bank dengan ukuran kecil. Peningkatan ukuran atau total aset bank dapat menyebabkan tingginya biaya operasional bank sehingga bank inefisien.

\section{e. Pengaruh Profitabilitas terhadap Tingkat Efisiensi}

Return On Asset (ROA) merupakan rasio antara laba sebelum pajak terhadap total asset yang dimiliki bank, apabila bank memiliki ROA yang tinggi menunjukkan bahwa bank tersebut memiliki kemampuan yang besar dalam meningkatkan laba (Fajria, 2016). Bank dengan ROA tinggi mencerminkan bank tersebut telah optimal dalam memperoleh pendapatan dari pengelolaan assetnya sehingga semakin tinggi ROA semakin efisien bank tersebut. Berdasarkan uraian tersebut dapat dipahami bahwa secara teoritik ROA berpengaruh positif terhadap tingkat efisiensi, yakni ketika ROA naik akan menyebabkan naiknya tingkat efisiensi.

Hasil penelitian menunjukkan bahwa profitabilitas tidak pengaruh terhadap tingkat efisiensi karena p-value $>0.05$. Berdasarkan hasil tersebut maka hipotesis kelima (H5) ditolak. Hasil tidak sesuai dengan dugaan awal penelitian yakni ROA berpengaruh positif terhadap tingkat efisiensi karena secara statistik tidak terbukti signifikan. Hasil temuan ini konsisten dengan penelitian yang dilakukan oleh Nurwulan (2012) yang menyatakan bahwa ROA berpengaruh positif tidak signifikan terhadap tingkat efisiensi.

f. Profitabilitas Memoderating Pengaruh Non Performing Financing (NPF) terhadap Profitabilitas

Semakin besar rasio NPF maka bank dalam kondisi semakin besar resiko pembiayaan yang dihadapi, tingginya resiko pembiayaan memberi peluang terjadinya penurunan pendapatan dari pembiayaan yang telah disalurkan bank (Windriya, 2017). Pengaruh langsung antara NPF dengan tingkat efisiensi adalah negatif (Irawanti, 2008) sedangkan pengaruh ROA terhadap tingkat efisiensi adalah positif (Pambuko, 2016). Berdasarkan uraian tersebut dapat dipahami bahwa secara teoritik ROA memperkuat pengaruh NPF terhadap tingkat efisiensi.

Hasil penelitian menunjukkan bahwa profitabilitas tidak mampu memoderating pengaruh NPF terhadap efisiensi karena $\mathrm{p}$-value $>0.05$. Berdasarkan hasil tersebut maka hipotesis keenam (H6) ditolak. Hasil tidak sesuai dengan dugaan awal 
penelitian yakni ROA memperkuat berpengaruh negatif NPF terhadap tingkat efisiensi karena secara statistik tidak terbukti signifikan.

g. Profitabilitas Memoderating Pengaruh Bank Size terhadap Profitabilitas

Semakin besar bank size maka bank tersebut memiliki lebih banyak modal yang dapat digunakan untuk mengadopsi teknologi baru yang dapat meningkatkan laba dan meminimalkan biaya. Sehingga profitabilitas bank akan baik dan bank semakin efisien (Damayanti, 2012). Berdasarkan uraian tersebut dapat dipahami bahwa secara teoritik ROA memperkuat pengaruh bank size terhadap tingkat efisiensi.

Hasil penelitian menunjukkan bahwa profitabilitas tidak mampu memoderating pengaruh NPF terhadap efisiensi karena p-value $>0.05$. Berdasarkan hasil tersebut maka hipotesis ketujuh (H7) ditolak. Hasil tidak sesuai dengan dugaan awal penelitian yakni ROA memperkuat berpengaruh negatif bank size terhadap tingkat efisiensi karena secara statistik tidak terbukti signifikan.

\section{PENUTUP}

\subsection{Kesimpulan}

Penelitian ini menganalisis pengaruh Non Performing Financing (NPF) dan Bank Size terhadap tingkat efisiensi bank umum syariah dengan profitabilitas sebagai variabel moderating. Berdasarkan hasil pengujian hipotesis dapat disimpulkan Bahwa : (a) Non Performing Financing (NPF) berpengaruh negatif signifikan terhadap profitabilitas bank umum syariah dengan nilai path coefficient sebesar -0.569 dan nilai p-value sebesar $<0.001$. (b) Non Performing Financing (NPF) berpengaruh negatif signifikan terhadap tingkat efisiensi bank umum syariah dengan nilai path coefficient sebesar -0.222 dan nilai p-value sebesar 0.046. (c) Bank Size berpengaruh positik tidak signifikan terhadap profitabililitas bank umum syariah dengan nilai path coefficient sebesar 0.164 dan nilai p-value sebesar 0.111. (d) Bank Size berpengaruh negatif tidak signifikan terhadap tingkat efisiensi bank umum syariah dengan nilai path coefficient sebesar -0.157 dan nilai p-value sebesar 0.112. (e) Profitabilitas berpengaruh positif tidak signifikan terhadap terhadap tingkat efisiensi bank umum syariah dengan nilai path coefficient sebesar 0.132 dan nilai p-value sebesar 0.165 . (f) Profitabilitas tidak mampu secara signifikan memoderating pengaruh Non Performing Financing (NPF) terhadap tingkat efisiensi bank umum syariah dengan nilai path coefficient sebesar 0.061 dan nilai p-value sebesar 0.330. (g) Profitabilitas tidak mampu secara signifikan memoderating pengaruh Bank Size terhadap tingkat efisiensi bank umum syariah dengan nilai path coefficient sebesar sebesar 0.207 dan nilai p-value sebesar 0.060 .

\subsection{Saran}

Implikasi dari kesimpulan ini adalah munculnya saran perlu dilakukan. Saran yang dapat disampaikan meliputi : (a) Bagi penelitian selanjutnya disarankan agar menambah variabel input, ouput dan independen lain yang mungkin dapat 
mempengaruhi tingkat efesiensi Bank Umum Syariah, serta menambahan periode penelitian agar dapat memberikan hasil penelitian dalam scope yang lebih luas. (b)Bagi praktisi bank syariah disarankan agar lebih meningkatkan tingkat efisiensi Bank Umum Syariah serta meminimalkan rasio Non Performing Financing. 


\section{DAFTAR PUSTAKA}

\section{Jurnal Ilmiah}

Abidin, Zaenal dan Endri, ( 2009), "Kinerja Efisiensi Teknis Bank Pembangunan Daerah: Pendekatan Data Envelopment Analysis (DEA)"Jurnal Akuntansi dan Keuangan, Vol. 11, No. 1.

Agriyanto, R (2015) Redefining Objective of Islamic Banking; Stakeholders Perspective In Indonesia. Economica, 6 (2), 77-90.

Ali, M. Mahbubi dan Ascarya, (2010), "Analisis Efisiensi Baitul Maal Wat Tamwil dengan Pendekatan Two Stage Data Envelopment Analysis (Studi Kasus Kantor Cabang BMT MMU dan BMT UGT Sidogiri)", Tazkia: Islamic Finance \& Business Review Vol. 5 No. 2.

Alifah, Umi, (2016) "Makna Tabdzir dan Isrof dalam Al-Qur'an", Skripsi, Fakultas Ushuluddin dan Pemikiran Islam UIN Sunan Kalijaga.

Choiriyati, Isny, (2011) "Pengaruh Motivasi dan Etos Kerja Islam terhadap Kinerja Karyawan (Studi Kasus pada Karyawan KJKS BMT Fastabiq di Pati )”, Skripsi, Jurusan Ekonomi Islam Fakultas Syari'ah IAIN Walisongo Semarang.

Damayanti, Pupik "Analisis Pengaruh Ukuran (Size), Capital Adequacy Ratio (CAR), Pertumbuhan Deposit, Loan To Deposit Rasio (LDR), Terhadap Profitabilitas Perbankan Go Public di Indonesia Tahun 2005-2009 (Studi Empiris perusahaan Perbankan yang Terdaftar di BEI)", Jurnal Ilmu Manajemen dan Akuntansi Terapan Vol. 3 No. 2, STIE Totalwin Semarang: hlm. 45-54.

Dewi, Dhika Rahma. "Faktor-Faktor yang Mempengaruhi Profitabilitas Bank Syariah di Indonesia",Skripsi, Fakultas Ekonomi Universitas Diponegoro Semarang, 2010.

Dewi, Kartika, (2016), "Analisis Efisiensi Teknis Perbankan Di Indonesia"Jurnal Manajemen Vol. 13 No. 2.

Fajria, Rola Nurul, , (2016) "Analisis Faktor-Faktor yang Mempengaruhi Profitabilitas Bank Umum Syariah di Indonesia pada Tahun 2011-2015”, Tesis, Pascasarjana Institut Agama Islam Negeri Surakarta.

Farandy, Alan Ray., Demas Asfario Suwito., Lila Kondi Dabutar, (2017) " Efficiency Of Islamic Banks In Indonesia: Data Envelopment Analysis", International Journal of Economics, Management and Accounting 25, no. 2.

Fidyaningrum, Apriliana dan Nasyitotul Jannah, (2016) “Analisis Penyelesaian Masalah Non Performing Financing (NPF) Pada Pembiayaan Murabahah Menurut Fatwa DSN No.47/DSN-MUI/II/2005 (Studi Kasus pada BMT Karisma Kota Magelang)", Jurnal Cakrawala, Vol. XI, No. 2.

Firdaus, Muhammad Faza, Muhamad Nadratuzzaman Hosen, (2013), "Efisiensi Bank Umum Syariah Menggunakan Pendekatan Two-Stage Data Envelopment Analysis",Buletin Ekonomi Moneter dan Perbankan.

Haq, Nadia Arini, (2015), "Pengaruh Pembiayaan dan Efisiensi Terhadap Profitabilitas Bank Umum Syariah".JurnalPerbanas Review.Vol. 1 Perbanas Institute Jakarta.

Hardiyanti, Widhian , (2015) "Analisis Pengaruh CAR. LDR, dan BOPO Terhadap ROA dengan NIM Sebagai Variabel Intervening (Studi pada Bank Umum di Indonesia Periode Tahun 2011-2013", Tesis, Program Studi Magister Manajemen Universitas Diponegoro Semarang.

Hidayat, Rahmat, (2011) "Kajian Efisiensi Perbankan Syariah Di Indonesia (Pendekatan Data Envelopment Analysis), Media Riset bisnis dan manajemen Vo1.11. No. 1. 
Irawanti, Luci, (2008), "Pengukuran Tingkat Efisiensi Bank Umum Syariah di Indonesia dan Analisis Beberapa Faktor Penentu". Tesis, Program Pascasarjana Universitas Indonesia.

JMV. Mulyadi, (2015), "Penilaian Efisiensi Bank dengan Data Envelopment Analysis pada 10 Bank Berperingkat Besar Di Indonesia", Jurnal Riset Akuntansi dan Perpajakan Vol. 2, No. 2.

Lemiyana dan Erdah Litriani, (2016), "Pengaruh NPF, FDR, BOPO terhadap Return On Asset (ROA) pada Bank Umum Syariah", I-Economic Vol. 2. No.1.

Liana, Lie, (2009) " Penggunaan MRA dengan SPSS untuk Menguji Pengaruh Variabel Moderating terhadap Hubungan antara Variabel Independen dan Variabel Dependen". Jurnal Teknologi Informasi DINAMIK Volume XIV, No. 2.

Maidalena, (2014), "Analisis Faktor Non Performing Financing (NPF) pada Industri Perbankan Syariah", Jurnal Human Falah: Volume 1. No. 1.

Muharam, Harjum dan Rizki Pusvitasari, (2007), "Analisis Perbandingan Efisiensi Bank Syariah Indonesia dengan Metode Data Envelopment Analysis (Periode Tahun 2005)", Jurnal Ekonomi dan Bisnis Islam Vol. II, No. 3.

Novandra, Rio, (2014), "Analisis Perbandingan Efisiensi Perbankan Syariah dan Konvensional Di Indonesia", Jurnal Ekonomi dan Pembangunan Vol 22, No. 2.

Nurwulan, (2012) "Analisis Pengaruh Bank Size, NPL, ROA, Kapitalisasi, dan CAR Terhadap Efisiensi Perbankan (Studi Pada Bank Umum dengan Total Aset Lebih dari Rp 30 Triliun Periode Tahun 2008-2010)“, Jurnal Studi Manajemen dan Organisa Vol. 9 N0. 2.

Pambuko, Zulfikar Bagus, (2016), "Determinan Tingkat Efisiensi Perbankan Syariah di Indonesia: Two Stages Data Envelopment Analysis", Jurnal Cakrawala, Vol. 11, No. 2.

Permana, Fafa Yushifa. Adityawarman, (2015), “Analisis Faktor-Faktor Yang Mempengaruhi Tingkat Efisiensi Perbankan Syariah Di Indonesia",Diponegoro Journal Of Accounting Vol. 4, No. 3.

Perwitaningtyas, Gloria Anindya, (2014), "Faktor-Faktor yang Mempengaruhi Efisiensi Bank di Indonesia Periode Tahun 2008-2012",Skripsi, Fakultas Ekonomi Universitas Diponegoro Semarang.

Pramudita, Aditya, (2013), "Pengaruh Ukuran Bank, Manajemen Aset Perusahaan, Kapitalisasi Pasar danProfitabilitas terhadap Kredit Bermasalah pada Bank yang terdaftar di BEI", Jurnal Ilmiah Mahasiswa FEB Vol. 2 No. 1.

Rahman, Aulia Fuad dan Ridha Rochmanika, (2012), "Pengaruh Pembiayaan Jual Beli, Pembiayaan Bagi Hasil, dan Rasio Non Performing Financing terhadap Profitabilitas Bank Umum Syariah Di Indonesia “, Jurnal Fakultas Ekonomi Dan Bisnis Universitas Brawijaya.

Rahmawati, Rafika, (2015), "Strategi Peningkatan Efisiensi Biaya pada Bank Umum Syariah Berbasis Stochastic Frontier Approach dan Data Envelopment Analysis",Buletin Ekonomi Moneter dan Perbankan, Vol. 17, No. 4.

Rahmi, Nurul., Ratna Anggraini, (2013) "Pengaruh CAR, BOPO, NPF, Dan CSR Disclosure terhadap Profitabilitas Perbankan Syariah", Jurnal Ilmiah Wahana Akuntansi Vol. 8, No. 2.

Restuningdiah, Nurika, (2010), "Kinerja Lingkungan Terhadap Return On Asset melalui Corporate Social Responsibility Disclosure", Jurnal Keuangan dan Perbankan Vol. 14, No. 2.

Stiawan, Adi, (2009), "Analisis Pengaruh Faktor Makroekonomi, Pangsa Pasar dan Karakteristik Bank Terhadap Profitabilitas Bank Syariah (Studi pada Bank 
Syariah Periode 2005-2008)", Tesis, Program Studi Magister Manajemen Universitas Diponegoro Semarang.

Sugiarto, Agus Sugiarto, (2004), "Mencari Struktur PerbankanYang Ideal”, Jurnal Bank Indonesia.

Wahab, (2015), “Analisis Faktor-Faktor yang Mempengaruhi Efisiensi Bank Umum Syariah di Indonesia dengan Pendekatan Two Stage Stochastic Frontier Aproach (Studi Analisis di Bank Umum Syariah)" Economica: Jurnal Pemikiran dan Penelitian Ekonomi Islam, Vol. VI, Ed. 2.

Wibowo, Edhi Satriyo., Muhammad Syaichu, (2013), “ Analisis pengaruh suku bunga, inflasi, BOPO, NPF terhadap Profitabilitas Bank Syariah”, Diponegoro Journal Of Accounting Vol. 2 No. 2: hlm. 1-10

Wicaksari, Erisa Aprilia, (2015), "Pengaruh Debt To Equity Ratio, Capital Expenditure dan Asset Tangibility terhadap nilai perusahaan dengan mediasi profitabilitas (Studi pada Perusahaan Manufaktur yang listed di Bursa Efek Indonesia Periode Tahun 2010-2013", Tesis, Program Studi Magister Manajemen Universitas Diponegoro Semarang.

Widayati, Tri, (2008)), "Analisis Efisiensi Teknis Tempat Pelelangan Ikan dan Tingkat Keberdayaan Pengelola Tempat Pelelangan Ikan Serta Strategi Pemberdayaannya di Wilayah Pantai Utara Jawa Tengah", Tesis, Program Pascasarjana Universitas Diponegoro Semarang.

Windriya, Anafil< (2017), "Pengaruh FDR, NPF, BOPO, dan Size terhadap ROA (Studi Komparatif pada Bank Syariah Indonesia dan Bank Syariah Malaysia Periode 2010-2015)", Tesis, Program Studi Magister Manajemen Universitas Diponegoro Semarang,.

Yahya, Muchlis, (2014), "Menakar Efisiensi BPRS Sebagai Bank Pembiayaan Rakyat Berbasis Bagi Hasil” Ekuitas: Jurnal Ekonomi dan Keuangan Vol. 18, No. 1.

Buku

az-Zuhaili, Wahbah, Tafsir Al-Munir Jilid 8, Jakarta: Gema Insani, 2016. , Tafsir Al-Munir Jilid 4, Jakarta: Gema Insani, 2016.

Dendawijaya. Manajemen Perbankan, Jakarta: Ghalia Indonesia, 2009.

Hidayat, Rahmat. Efisiensi Perbankan Syariah: Teori dan Praktik, Bekasi: Gramata Publishing, 2014.

Machmud, Amir dan Rukmana. Bank Syariah: Teori, Kebijakan, dan Studi Empiris di Indonesia. Jakarta: Erlangga, 2010.

Mawardi, Wisnu. Membangun Model Profitabilitas Bank Melalui Kualitas Kompetensi Fungsional Kredit dan Pengunaan Teknologi Informasi Berbasis Pendapatan, Semarang: Pustaka Magister, 2014.

Nopirin. Pengantar Ilmu Ekonomi Makro dan Mikro. Yogyakarta: BPFE, 1997.

Siamat, Dahlan. Manajemen Lembaga Keuangan Edisi Kelima. Jakarta: Lembaga

Penerbit FE UI, 2005.

Suhada, Bank Syariah, Bandung: Gema Buku Nusantara, 2009.

Trisadini, Transaksi Bank Syariah, Jakarta: Bumi Aksara, 2013. 